\title{
Online Teaching at the Universidad Veracruzana: Emerging Strategies and Challenges
}

Summary: In this paper, we briefly dissert past pandemics throughout history before addressing Covid-19. The objective is to describe the effects it has had on higher education and especially language, translation, and research teaching, as well as the challenges that have been faced with shifting from face-to-face lessons to online learning with help from information technologies. The advantages and disadvantages of this educational approach in a postgraduate context are reviewed, and the solutions that had to be implemented to offer quality education and avoid negative consequences for students' learning. This project explains the strategies applied by the authorities, professors, and students at the Universidad Veracruzana. It is a qualitative interpretative study in which the data was collected through semi-structured interviews. The most interesting findings were the writing and speaking improvements of the students, given the thorough review from their professors and peers. Moreover, they learned to construct their knowledge and become more autonomous in search of solutions to the problems during confinement. At the same time, the professors learned to operate multiple e-learning platforms so as not to stay behind. In conclusion, all involved learned to be more resilient and positively look at life, despite the obstacles.

Keywords: distance education, teaching, electronic learning, postgraduate courses, higher education.

1 piliortiz@yahoo.com 


\section{Introduction}

Education worldwide has undergone radical changes due to the appearance of Covid-19. Its speed of infection and harmfulness has caused schools to operate in a distance-learning mode. In some countries, the infrastructure for virtual education was already in place, and both students and teachers had the necessary resources to continue their academic activities without significant inconveniences. However, according to Gómez \& Martinez (2021), the digital divide in Mexico has increased during the pandemic in rural and indigenous areas due to the low investment made by telecommunication companies. Furthermore, there is a limited availability of electronic devices due to the population's economic factors and education levels (Gómez \& Martínez, 2021).

In some graduate programs at the Universidad Veracruzana, the obstacles that would prevent effective education may have been overcome due to the National Council for Science and Technology scholarships; those help students to buy electronic gadgets and pay for Internet service. This research aims to describe the effects the pandemic has had on higher education and especially language, translation, and research teaching, as well as the challenges that have been faced with shifting from face-toface lessons to online learning with help from information technologies.

\section{The origins of pandemics}

According to Martínez (2020), fear is the first human reaction to pandemics, followed by the desire to flee. However, he reports that there are always people interested in research, so the need for observation prevails. The second reaction when one is in the center of disaster is to look for culprits. This author also mentions that men have difficulty avoiding guilt; thus, epidemics are perceived as a punishment, he states:
"About twenty thousand years ago, on a stormy sunset, the sorcerer Cro-Magnon was returning from a retreat of several days in the mountains, where he had been collecting magic herbs when he was informed that one of the men of the town had arrived sick from a long hunting day. Convinced of his healing power, the sorcerer covered himself in his deer garb and went to see him. He pushed aside the leather that covered the entrance to the cave and illuminated the sick man with his torch. He immediately gave a start, recoiled in terror, ordered to break camp, and flee to an uncertain end in the middle of the night. In the pustular face of the sick man, he had recognized some plague (perhaps smallpox), the horrifying image of which he had received through successive accounts of his father and his grandfather, and he knew that death was inevitable." (Martínez,2020:1)

Martínez (2020) recounts that the first significant pandemic occurred in the time of Emperor Justinian in the 6 th century AD and lasted 60 years. Then, the black death appeared and ravaged all of Europe between 1347 and 1382. In Boccaccio's Decameron, the concepts of isolation and contagion had already existed (Martinez, 2020). During the first pandemics, it was seen that the risk of becoming ill increased when approaching a patient, as well as touching the corpses' clothes. The consequences were flight and quarantine. In the middle of the 19th century, the concepts such as incubation appeared, and quarantine was widespread to avoid infectious diseases; outbreaks often provoke hysteria leading to the stigmatization of minority populations. In 1918, the Spanish flu killed between 40 and 100 million people in the world in a single year. As a result, measures such as personal hygiene and isolation of those affected were implemented.

The 21st century has brought new epidemic threats, such as the Asian pneumonia in 2003. Then, in 2014, the Ebola virus reemerged in West Africa and triggered the cancellation of international flights and high economic losses. In 2009, the $\mathrm{H} 1 \mathrm{~N} 1$ virus was detected in the United States and 
Mexico and on April 25 of the same year, the World Health Organization declared a public health emergency and officially deemed it a pandemic. In our days, terror reemerged in 2019. The Covid-19 virus reminded us that random death, fear, rejection, and segregation come with every plague; therefore, confinement began all over the world.

\section{Covid-19 overview in Mexico}

In Mexico, the first case of the virus was detected on February 27, 2020. The carrier was a Mexican citizen bound from Italy. On March 24, phase 2 of the pandemic began, and economic activities were suspended. As well as avoiding mass gatherings, the authorities recommended remaining housebound, and the slogan Stay at home appeared everywhere.

A few days later, non-essential activities were suspended, except security, health, energy, and cleaning services. On radio and television, constant hand washing and disinfection of public areas were advised. Face masks became mandatory when going to public places to avoid contagion, and by March 30, the national health emergency was decreed. Later, Mexico's Department of Higher Education (2020) implemented several actions. For example, reporting confirmed Covid-19 cases to the authorities and preventing the spread of fake news. Children, who had the necessary means, were able to continue studying through television and distance lessons. However, those from marginalized groups ran the risk of being left behind. Teachers were required to adapt to the new pedagogical concepts for which they had received no previous training.

Since the beginning of the pandemic, the Universidad Veracruzana has followed the instructions of Mexico's Ministry of Health. They established an epidemiological traffic light on which the restrictions for the population were based to avoid the spread of Covid-19. This traffic light establishes four levels of alert: red, orange, yellow, and green. It is based on four aspects representing the impact of the disease: interpersonal transmission, territorial spread, response capacity, and health consequences.

Each month, the university mirrors the color of the traffic light for the community to follow. At the time we write these lines, August 17, 2021, it is reported that although the Federation places the state of Veracruz in yellow, the institution refers to the risk levels established by the state government, so the campuses in the cities of Xalapa and Veracruz are in orange and red, respectively. This decision means that academic activities will continue at a distance and library activities will be allowed up to $50 \%$ capacity.

Many higher education institutions worldwide had some resources to manage online teaching before the appearance of Covid-19. However, the training that would allow its correct use among the school community was missing. The Universidad Veracruzana prepared for distance learning almost 20 years ago with the creation of the Eminus system. This software integrates the functions of most commercial software, such as structuring of thematic units with various types of multimedia, the design of online evaluations, and a videoconferencing system. In the end, Eminus was not used by many professors. Instead, they used the tools they already knew well, for example, those developed by Google, Zoom, and other companies. Online teaching is also based on the well-known pedagogical theories.

\section{Literature review}

Epistemologically, education in a virtual modality is based on three popular pedagogical perspectives: behaviorism, cognitivism, and constructivism (Ally, 2004). The first is reflected in the activities programmed in a virtual language course, where the teacher codes a series of exercises to evaluate the students' knowledge. Through these, the student is forced to prepare the topics before solving the questionnaires. On the other hand, those theories that prioritize cognitive processes as the main vehicle for 
learning advocate for two primary elements: memory and individual differences (Ally, 2004). For example, if a virtual lesson is presented mainly in plain text, with no highlights of any kind, the student will probably have difficulty remembering its contents or meaningfulness. In other words:

\begin{abstract}
"The pandemic has accelerated a process of digitization that adds other peculiarities. It is about a more demanding read: the text is not physically in the environment; you have to find it in the cloud, requiring specific technical and cognitive skills. You have to manage apps, browse the web, move tactilely through the tiny pocket screen. Mentally you have to reconstruct the circumstantial context of each writing (the restaurant menu, the hand program, the map)." (Cassany, 2020: n.d.)
\end{abstract}

Some studies mention the advantages and disadvantages of distance education. For example, Arkorful and Abaidoo (2015) report that some advantages are the time and space flexibility that virtual lessons offer, the easiness of obtaining information online, and, for asynchronous learning, the possibility that students review class materials at their own pace and learning style. Borstoff and Lowe (2007) point out that lower expenses for students and professors are also favorable. On the other hand, Arkorful and Abaidoo (2015) also claim that some disadvantages are the lack of personal interaction, the difficulty of answering students' questions through a computer, and problems that arise with assessing online activities, given the possibility of cheating. Other disadvantages mentioned are: "bandwidth issues, $[\ldots]$ lack of human contact, [...] and technical difficulties (Borstoff \& Lowe, 2007:17).

The strategies used by teachers and students during online education should also be considered. Studies such as Bailey and Card (2009) emphasize the importance of fostering student-teacher relationships and the commitment of everyone involved to establish constant communication through different technological tools. Moreover, they claim that there must be an agreement in the group regard- ing the distribution, creation, and assessment of assignments and projects punctually and appropriately and establishing learning goals clearly at the beginning of the course, and its development (Bailey \& Card, 2009). This situation strengthens the role of the professor as a facilitator and impacts the students' autonomy to improve their knowledge.

Other studies affirm the challenges that virtual teaching and learning involved. Jacobs (2013) claims that learning should focus on the students to develop their motivation, independence, and active participation in solving real problems. However, in Mexico and Latin America, the main challenges are technological (Ontiveros \& Canay, 2013). These include, but are not limited to, issues relative to the digital divide, such as infrastructure costs and a stable Internet connection, and poor knowledge in using various technological tools. This problem is stressed in marginal areas. Jacobs (2013) explains a false belief that young students are capable of handling these tasks. Nonetheless, using technology to communicate or publish posts on social networks differs from its educational purposes. This difference could mean there is a need for training and practice to accomplish academic tasks online.

Finally, students' writing could benefit from online feedback from their professors and peers. This process can occur through electronic means (email, instant messaging, word processors, or online apps). A study conducted with foreign language students (Tai, Ling \& Yan, 2015) concluded that peer-review and professor input and corrections, enhance feedback usefulness and quality. Similarly, McVey (2008) mentions that teachers should personalize their comments according to their students' needs and balance positive and negative observations.

\section{Research design}

This research was carried out during the January-June 2021 semester with professors and stu- 
dents from the Institute for Education Research of the Universidad Veracruzana. The project used a qualitative approach since it seeks to understand "how people interpret their experiences, how they construct their worlds and what meaning they attribute to their experiences" (Merriam \& Tisdell, 2015: 6).

Semi-structured interviews were used to collect the data. This method allows "finding out things that cannot be directly observed [such as] feelings, thoughts and intentions" (Patton, 2014: 426). The selection of this technique responds to the duty of profoundly understanding the participants' perceptions, and it fits the aim of describing the effects the pandemic has had on higher education and especially language, translation, and research teaching, as well as the challenges that have been faced with shifting from face-to-face lessons to online learning with help from information technologies.

The informants were 11 professors and 10 students due to the sufficient and meaningful data they provided. The professors teach their classes in foreign languages, specifically in French or English. The students have different personal and academic backgrounds. The criteria to participate in the study were to belong to any of the institute's educational programs during January-June 2021. In addition, the students must have submitted homework, reports, or thesis extracts throughout the semester.

The participants' voices give meaning to reality at a given moment; in our case, they are the opinions of professors and students who interact under a virtual modality within an institute of the Universidad Veracruzana. An interpretive constructivist stance is taken to elucidate the meanings that participants assign to their experiences within educational programs and explain how they have overcome obstacles and exploited areas of opportunity that arose during online classes.

The ethical considerations met during this research respond to the global need to respect the integrity of the participants (Neumann, 2014). Be- fore starting the project, the students and professors signed informed consent. This document "explains aspects of a study to participants and asks for their voluntary agreement" (Neumann, 2014:151), therefore, to report the findings in this research, pseudonyms were used instead of the participants' real names. It states that their rights as participants will be respected and that if they felt uncomfortable or disagreed with something, they could withdraw from the study at any time.

\section{Findings}

The findings are divided into four different categories: 1) the advantages and disadvantages of online teaching and learning of language, linguistics, and translation in higher education; 2) the strategies used in distance learning; 3 ) the challenges met by the participants regarding to online education and, 4) the influence of online lessons in the students' writing.

\section{Advantages and disadvantages of online teaching and learning}

For professors, one of the advantages of online education is the ease of time management and decreasing travelling inconveniences. They also believe that students and their families spend fewer resources and reduce vehicles on the street. These views mostly coincide with Arkorful and Abaidoo's (2015) findings about time and space flexibility of distance learning. They mention that it is easier to help students in distant places through virtual lessons and courses. Moreover, they claim it is possible to use different teaching materials. Professor Tania comments:

\footnotetext{
"We can have students from any region of the world as part of our school enrollment. There are no transportation costs; vitally crucial in a country with poor transportation. Students are not exposed to danger on the streets. [Besides,] the study material is cheaper." (Professor Tania)
} 
For students, the main advantages are that individual and collective knowledge can be shared more easily. Conrado mentions:

\begin{abstract}
"You can, [...], attend a course in Italy (for free) in the morning, another in the US in the afternoon, listen to a lecture, and participate in the evening. Thanks to distance education, it is possible to access materials and resources that were previously ephemeral (an unrecorded book presentation, a talk that was only given in a seminar, an untranscribed interview) and private (such is the case of many academics who have shared the links to their courses)." (Professor Conrado)
\end{abstract}

Learners also mention that they can achieve greater autonomy at work due to independence and responsibility. They also comment that online tools have favored their punctuality habits, saved universities' expenses in goods and services, and the ability for each learner to work at their own pace, as pointed out by Arkorful and Abaidoo (2015).

Some of the main disadvantages for professors, as Manuel points out, are

\section{"...the lack of equipment and infrastructure which causes frustration and anxiety since it is necessary to invest in [...] a suitable workplace and the necessary equipment [...]. Eye contact with the students is lost, some of them turn off their videos and [...] dedicate their time to other activities, [...] formality is lost." (Professor Ma- nuel)}

Socioeconomic differences are also heightened, as pointed out by Professor Guillermo:

"The connectivity problems and the socioeconomic status of several students, especially undergraduate students, but also graduate students living in indigenous communities, have generated inequalities in the use of online learning. The university has not been able to ensure equitable connectivity for its students, which generates institutional discrimination." (Professor Guillermo)
For students, the main disadvantages of online education are 1) the tendency to procrastinate and 2) physical and mental health is affected by remaining in front of the computer for long periods. Also, some learners have been anxious because they can no longer do in-person fieldwork. They added that many disadvantages relate to socioeconomic situations since low-income students have more difficulty accessing information technologies.

Two disadvantages that almost all the participants point out are the lack of interaction between professors and students and the difficulty of carrying out collaborative work, which affects the creation of bonds between them. Professors also claim that exposure to various distractors at home affects the student's attention span. They state that online education is not synonymous with justice, equity, and democracy, which should be the principles of any educational system. Some professors forget that not all students learn at the same pace, yet the usual learning style is privileged.

Another drawback is the belief that being homebound, people have to be available at any time, even on weekends. The participants are concerned about the depersonalization of the educational process; they think the discussions held in class or when coffee was shared during breaks are necessary. Luis comments:

"I believe that there is a condition of dehumanization and individualism in this stage of the pandemic; [...] The warmth of the face-to-face spaces is not replaceable by the labyrinths of solitude to which the virtual connection leads." (Luis)

\section{Strategies in distance learning}

Professors comment that they organized online sessions with the students through different platforms every week. Regarding the strategies used for virtual teaching, there are written reports or essays, having students participate in class, and adaptations to the didactic materials. Some professors 
mention the distribution of texts throughout their course and the request for written reports to verify understanding of the topics. Such is the case of professor Alba, who states that she provided "the students with a program and all the readings materials that [they] reviewed [...] in digital [format]. They did the reading, and I asked them about it [and] they gave me a reading report".

In addition, certain professors explain the importance of peer or workgroup review to check student progress. For example, Professor Juan mentions:

"For me, it was important that in the session, they deliver a summary, synthesis, or short essay after each class, according to the topic that had been presented. In their writing it was clear who had been attentive to the class's progress and who had only listened to parts of the session." (Professor Juan)

The most sought-out activities to maintain attention and participation during the synchronous sessions were presentations, debates, and group feedback organized by the learners. In addition, time management during sessions is considered crucial to avoid boredom and monotony. Professor Manuel comments that:

"Two moments are stablished to avoid fatigue and monotony, thinking about classes of 4 or 5 hours. First, content presentations or readings [are shown], [then] a break of 15 or 20 minutes. [After that], questions and doubts, comments and reflections on concepts or topics derived from the authors and readings discussed." (Professor Manuel)

In the same vein, Professor Juan expresses that "... it was important that [the students] spoke, that they took initiatives of participation, made presentations, asked questions and at least were present with their voices". This fragment matches the findings of Bailey and Card (2009), where teachers mentioned that group communication and timely feedback is essential for effective learning.
Most learners emphasized the organization and personal discipline they implemented during confinement to meet their academic commitments. Ariana mentions that "it was necessary to plan schedules and maintain the routine to meet the objectives of the planned school year". Homero comments that to stay organized; he had to "take notes in Word or on paper; [...] Identify the key points of the class to return to later; [...] Listen to [his] classmates and professors to learn from their opinions, experiences and appropriations of the subject to be analyzed".

\section{Challenges in online education}

As pointed out by Ontiveros and Canay (2013), three main themes prevail for teachers:

1) the shortcomings in terms of technological infrastructure and its proper use

2 ) the rules of organization in a virtual environment

3) the motivation of the students to participate during the sessions.

The lack of devices in good condition in the household, and stable Internet connection that allows the punctual and permanent attendance of the students to the scheduled sessions constitute the two main challenges that stand out in the first theme. For example, Professor Alba mentions that it is difficult for students to "... connect on time. Sometimes I could not do it with bad weather, or the signal strength is feeble". Professor Guillermo summarizes that:

\begin{abstract}
"The main challenge is the inequality that generates or deepens among our students: students from rural or urban-popular contexts, and indigenous students are much more affected by digital gaps. [Moreover] these are aggravated by the socioeconomic situation that their families and homes are going through." (Professor Guillermo)
\end{abstract}

Professor Sabino mentions that it is necessary to "improve Internet access, but at the same time to 
create institutional conditions so that students who lack adequate equipment can access them (diagnosing who requires special support)." On the other hand, it is also mentioned that, despite having adequate resources, training is required for their correct use. Professor Carlos expresses that it is necessary "to train teachers, students and administrative staff in the efficient use of these technologies." Distance education's ethical and interaction considerations arising from distance education are also mentioned, given the little familiarity with these virtual environments. Professor Carlos summarizes that it is vital:

"To become aware of the social and cultural impact that living with others in a virtual ecosystem entails, which immediately translates into implementing clear protocols for coexistence, as well as the implementation of new collaboration strategies, considering that teamwork is carried out remotely, always respecting the private life of the members of such an ecosystem." (Professor Carlos)

Another critical factor is the motivation of the students to participate in the virtual sessions, which is similar to Jacob's (2013) argument that active participation online is crucial. In particular, Professor Juan points out that "it is difficult [because] sometimes students turn off their camera and video in practically all cases, and there is the feeling that they are only speaking in front of a computer." Also, Alba states that "the main challenge is to convince students to interact in class."

Regarding students' perceptions, the three challenges above appear similarly. The lack of technology or its stability is an issue mentioned by some participants. For example, Ariana comments that "something which frequently interrupted the sessions was the instability of the network." Gonzalo mentions that "sometimes there were technical problems related to the quality of the Internet and the performance of [his] laptop, which made it difficult [...] to take the lessons". These statements could be because of the remote location of the interviewees, where the connection to the network contin- ues to be poor, as claimed by Gomez and Martinez (2021).

The second predominant theme is the customization of a workspace in the students' homes; multiple interferences could hinder work and concentration by staying at home. Homer comments that it was necessary to "adapt a space for [the] lessons in which there was no noise or distractions." Similarly, Yuridia expresses that she had to control "noises at home [as well as] to cope with external sounds," and Conrado states that he had to "build his own space for intellectual creation and development" so as not to obstruct his virtual learning.

Third, most students report that they had to learn to use the technological tools chosen by the professors. This situation is very similar to Jacobs' (2013) findings of youth's technological skills. Furthermore, learners claim that adapting to the virtual learning modality was necessary, which generated a greater demand for self-learning and responsibility. For example, Homer comments that it was necessary to "learn to use Zoom, [Google] Meet, and Microsoft Teams." Mario concurs that "mastering the software to take class sessions, [...] from knowing how to start, up to using all the tools available in the meetings", was unavoidable.

Finally, some informants indicated some affections in their emotional state due to confinement. Luis indicates that his main challenge was coping with

"Loneliness. Standing in front of a screen without having actual contact with other people has not been easy. The emotional side has been compromised with this type of work, and concentration and mental health." (Luis)

Yolanda identified "new socio-emotional reactions such as stress, despair, among others," and Gonzalo felt "unable to learn because the interaction process through the computer was hampered." 


\section{Online lessons and their influence on students' writing}

The postgraduate professors, in general, are not very satisfied with the progress of their students in terms of writing, Professor Manuel comments:

\begin{abstract}
"In general, they express themselves and make use of writing clearly, but there are mistakes in specific uses of academic writing, which even when they are taught models, it is difficult for them to assimilate and apply without it being clear since it is nothing more than adopting a pattern. [...] At the end of the course, there are specific improvements, but slow progress is observed." (Professor Manuel)
\end{abstract}

They mention that students are used to being corrected and do not bother to review what they will turn in carefully. Also, they do not know how to use word processors properly. Other professors think there were setbacks in writing because learners are more exposed to poorly written materials and consult electronic sources that do not use academic language. They think that this reflects, in a way, that professors continue to be an essential reference in the educational process. Moreover, they believe in systematizing, classifying, and distinguishing worthwhile from trivial information. They also comment that they carefully reviewed all the essays and these chapters submitted by the students and marked their corrections using the Track Changes tool in Microsoft Word. Professor Tania comments:

"I used the writings at the end of each unit. I offered Zoom sessions to discuss the pre-writing process (few were online). Subsequently, the Zoom session became a Writing Center for students who required it." (Professor Tania)

Students also point out their progress in writing and comment that they could write better in less time, thanks to the feedback they received. This idea concurs with Tai, Ling \& Yan's (2015) research, especially when learners received feedback from peers and professors. Furthermore, they learned to express the main ideas in their theses, and their reading comprehension of scientific texts improved. Others indicate that the confinement provided them enough time to write, rewrite and contact authors from other countries and working groups. They were also able to share their texts with more people and receive recommendations from other authors and seminars. Homero explains what helped him improve his writing:

"Regularly, we wrote reading reports on the topics to be analyzed in the different sessions. These were reviewed by the professor, who pointed out the mistakes or issues that could be improved. However, not all professors send feedback on our work. In addition, the students of this course had to review the reading reports of our classmates, which helped us identify linguistic and extralinguistic errors and learn other ways of interpreting the document. In the end, we made a portfolio with all the tasks; this evidenced our progress in writing and academic argumentation." (Homero)

Some students commented that they were aware of the importance of writing because it took two or three hours to review a paper, so as not to deliver something inconsistent. Others mention that they improved their academic writing thanks to the comments made by the students about their schoolwork, and in this way, they learned to argue and strengthen the syntactic, semantic, and pragmatic aspects of the writing process. As McVey (2008) shows, professors' comments appear in different ways and means, balancing positive and negative aspects. Learners agree that writing is key to efficient communication, starting with emails, as they have the most significant impact if on getting a positive response. In general, they comment that they have noticed progress throughout each semester, as they write better at the end of the school year. 


\section{Conclusion}

The pandemic has urged us to reflect on the need to ensure that all young Mexicans from urban, rural, and indigenous environments have the opportunity to attend school and develop their knowledge, skills, attitudes, and values, which allow them to contribute to society. Educators must be prepared because perhaps lessons will occur in a hybrid format, and there should be training on how to use different software, video channels, online dictionaries, and other technologies. The digitalization process has quickened, and if we are not competent, both teachers and students will continue to suffer from stress and anxiety.

We have changed the physical copies of books for computers, mobile phones, WhatsApp texts, $P D F$ files downloaded from the Internet, but we continue doing almost the same tasks: teachers prepare the programs and distribute assignments at the beginning of the courses; the students comment and prepare reading reports, essays, and theses. Some professors refuse to review online; others understand that doing it carefully from the beginning and being strict about writing will pay off for everyone, as the time invested will be more than rewarded by seeing their students' progress.

At first, it was thought that it was straightforward to change face-to-face for online classes, with the exact schedules, programs, and objectives, but we soon realized how difficult and tiring it is to spend several hours in front of the screen. Some students turn off their video cameras and dedicate their time to other activities. Hence, the professor does not have the same control as in an in-person class. Among the main advantages of the new modality for professors were fewer inconveniences in transportation, traffic reduction, and the chance to work with learners in remote locations. Likewise, the students value their independence and increased responsibility during their virtual education. Also, they seem to appreciate how online learning forced them to be punctual and that professors and tutors are available to support them.

Both students and professors agree that México's main disadvantages and challenges for online education are the lack of technology and training, especially for rural learners. Furthermore, the limited human contact during online lessons is also a concern. Regarding writing progress, the professors are not generally satisfied, but the students are. A possible solution appears to be the level and quality of the feedback received by peers and tutors. Moreover, learners report being more thorough now that their academic independence has been strengthened. Now the challenge is to, as much as possible, build a more resilient and just society. Nevertheless, if we are optimistic, our vision of the past teaches us that humanity ends up prevailing even through the most devastating epidemics.

\section{References}

- Ally, M. (2004). Foundations of educational theory for online learning. Theory and practice of online learning, $2,15-44$.

- Arkorful, V. \& Abaidoo, N. (2015). The role of e-learning, advantages, and disadvantages of its adoption in higher education. International Journal of Instructional Technology and Distance Learning, 12 (1), 29-42.

- Bailey, C. J. \& Card, K. A. (2009). Effective pedagogical practices for online teaching: Perception of experienced instructors. The Internet and Higher Education, 12 (3-4), 152-155.

- Cassany, D. (2020). Letrismo en la época de la Covid19. Jardín LAC. Lectura, arte y conversación en (y para) el espacio público. Retrieved April 18, 2021, from www: https://www.jardinlac.org/post/letrismo-en-la-epoca-de-la-covid19-1-de-3 
- Gómez, D. A. \& Martínez, M. (2021). Brechas digitales indígenas en tiempos de Covid-19. Ichan Tecolotl, año 32, edición 349, junio 2021. Publicación mensual editada por el Centro de Investigaciones y Estudios Superiores en Antropología Social (CIESAS). Retrieved May 11, 2021, from www: https://ichan.ciesas.edu. $\mathrm{mx} /$ brechas-digitales-indigenas-en-tiempos-de-covid-19-2/

- Jacobs, P. (2013). The Challenges of Online Courses for The Instructor. Research in Higher Education Journal, 21, 1-18.

- Martínez, J. M. (2020). Las pandemias a través de la historia. La nueva crónica - diario leonés de información general, 11 de mayo de 2021. Retrieved April 26, 2021, from www: https://www.lanuevacronica.com/laspandemias-a-traves-de-la-historia\#cuerpo_noticia

- McVey, M. (2008). Writing in an Online Environment: Student Views of „Inked“ Feedback. International Journal of Teaching and Learning in Higher Education, 20 (1), 39-50.

- Merriam, S. B. \& Tisdell, E. J. (2015). Qualitative research: A guide to design and implementation. New Jersey: John Wiley \& Sons.

- Neuman, L. (2014). Social Research Methods: Qualitative and Quantitative Approaches. Essex: Pearson

- Ontiveros, M. \& Canay, J. R. (2013). Education and Technology in Mexico and Latin America: Outlook and Challenges. Introduction. In: Education and Technology in Mexico and Latin America: Outlook and Challenges. Universities and Knowledge Society Journal (RUSC), 10 (2), 407-413.

- Patton, M. Q. (2014). Qualitative research \& evaluation methods: Integrating theory and practice. Thousand Oaks: Sage publications.

- Secretaría de Educación Pública. Subsecretaría de Educación Superior (2020). Comunicado a los titulares de los subsistemas e instituciones de educación superior del país. Retrieved from www: https://www.fimpes.org. $\mathrm{mx} /$ covid19/images/banners/doctos/comunicado_f2.pdf

- Tai, H. C., Lin, W. C. \& Yang, S. C. (2015). Exploring the effects of peer review and teachers' corrective feedback on EFL students' online writing performance. Journal of Educational Computing Research, 53 (2), 284-309. 


\section{Марија дел Пилар Ортис Ловиљо, Данијел Хакобо Хиди Марти}

Универзитет у Веракрусу, Институт за педагошка истраживања, Мексико

\section{ОБРАЗОВАЊЕ НА ДАЉИНУ НА УНИВЕРЗИТЕТУ ВЕРАКРУСАНА: НОВЕ СТРАТЕГИЈЕ И ИЗАЗОВИ}

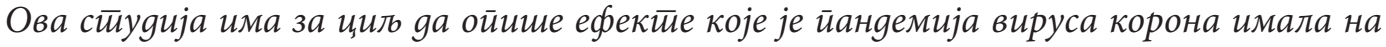
високо образоване, а йосебно на настиаву језика, ӣревођена и иситраживана, као и изазове са којима се суочава ирелазак са часова уживо на онлајн-учене, иомоћу информационих йехнолоіија. У Мексику су, за разлику о развијенијих земаља, ирримейни неgосииаии у оиремље-

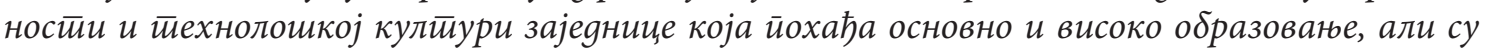
ироблеми више наїлашени у руралним и ауйохйоним среgинама.

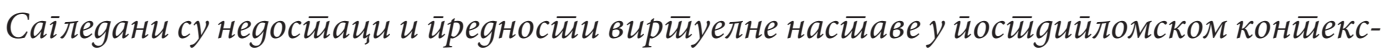

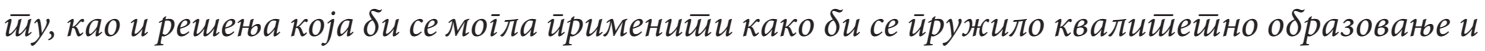

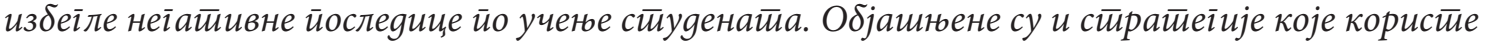
уйрава, ирофесори и сииуяентии Универзииетиа Веракрусана. Истираживане је сировеgено йоком семестира фебруар-јун 2021. іолине на јеgном исираживачком инсиичйуйу ӣри мексичком gржавном универзитетеиу, у яржави Веракрус.

Теоријска основа онлајн-учења стична је оној у настиави уживо. Она обухвайа кон-

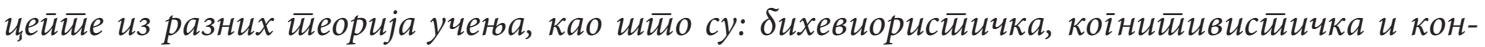

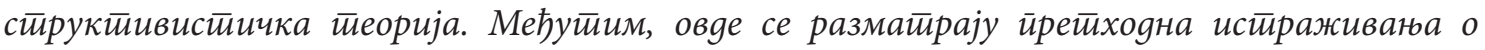

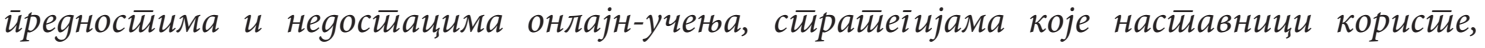
најзначајнијим изазовима, и како сииалне йоврайне онлајн-инбормације моїу gа йобољиају

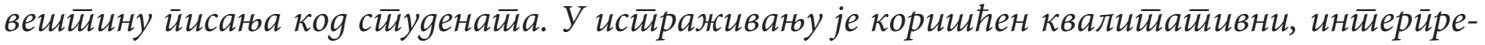

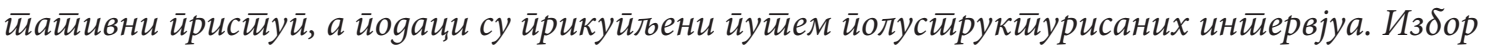

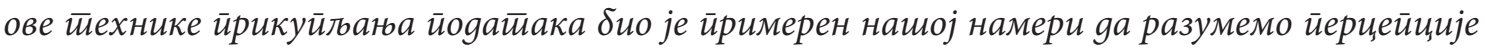

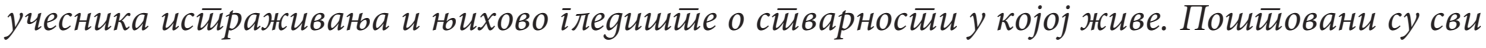

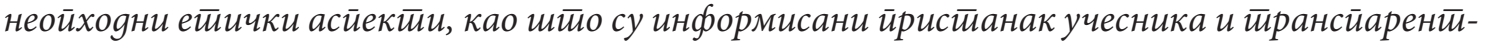

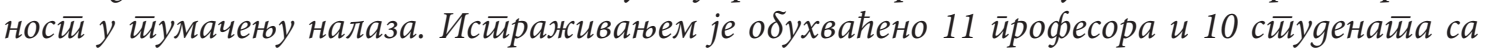

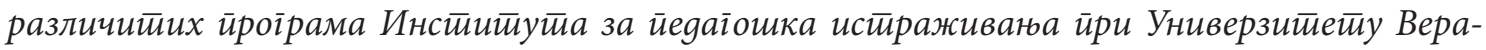
крузана.

Међу најзанимљивијим налазима исирраживана био је йоgатиак gа йрофесори сма-

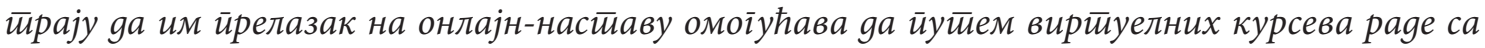

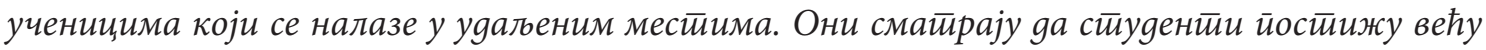
ауйономију у раgу, јер имају осећај самосииалностии и оgі̄оворнији су у йроцесу обуке. Шйа-

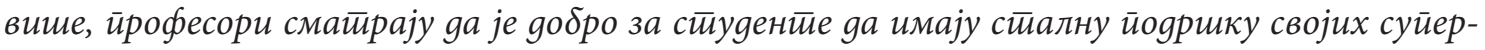

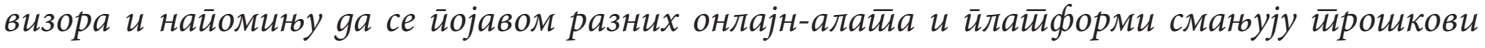

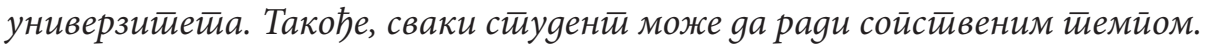

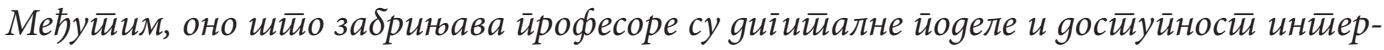

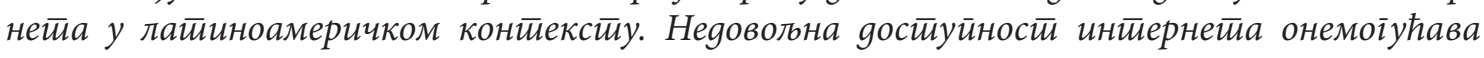




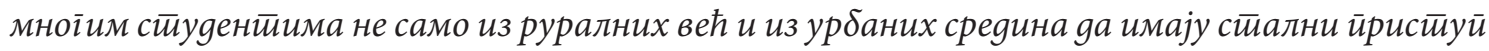

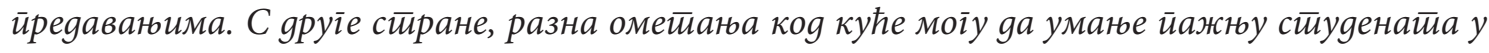

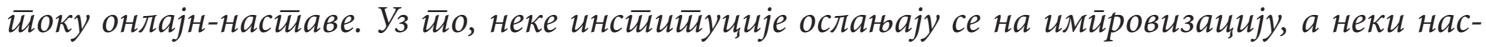

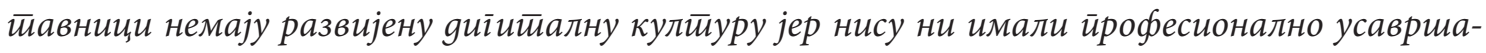

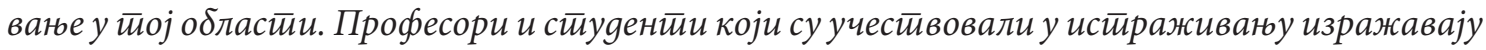
забринуйости у вези са неgоволном иниееракиијом у йоку онлајн-настиаве и иеткоћама на које наилазе у йоїлеgу колаборайивноі раяа. Ови ирроблеми оиежавају стиваране чврићих

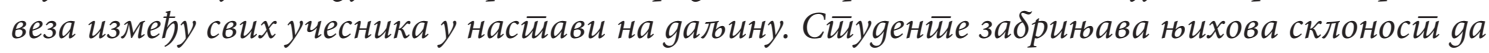
оgуіовлаче и смайрају gа је юихово йсихичко и физичко здравље уірожено јер морају мноїо времена gа ӣровоgе исирреg екрана комӣјуйера и не моїу gа се виђају са йријайељима и члановима йородице. Неким сйуденйима сметиа ийо више не моїу gа се баве исираживачким

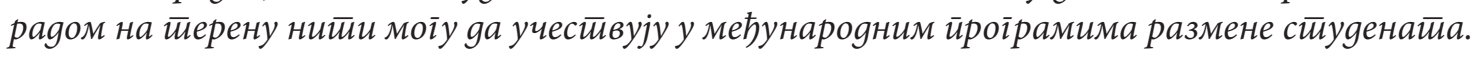

Уочен је найреgак коg сйуgенайа у йоїлеgу развоја вешитина йисань и усмене кому-

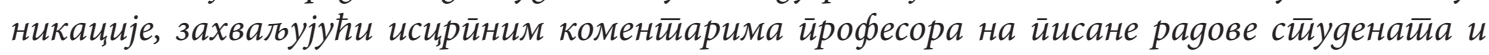

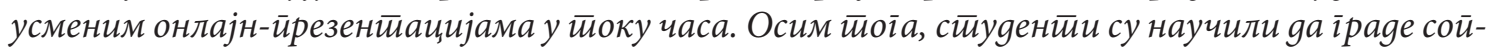
сиивено знане и йраже решена за разне йроблеме у йоку раgа оg куће. Каgа је реч о йрофесо-

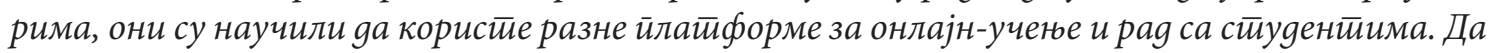
закључимо, сви учесници истираживана научили су gа буgу от̄ӣорнији и gа на животи ілеgају йозитиивно уйркос йоиеиккоћама.

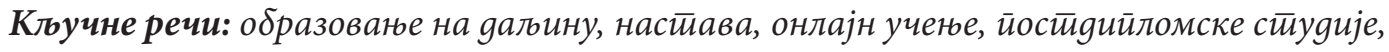
високо образоване. 